\title{
A Physiological Approach: Nitrogen Management and Sub-1 Rice Varieties Grown in Flood Prone Ecosystem
}

\author{
Anand Kumar Pandey*, A. K. Singh, Alok Kumar Singh and R. K. Yadav \\ Department of Crop Physiology, A.N.D.U.A\&T, Kumarganj, Ayodhya (U.P.), India \\ *Corresponding author
}

Keywords

Physiology

Approach; Nitrogen

Management; Flood

Prone; Sub-1; Rice

Article Info

Accepted:

05 April 2020

Available Online:

10 May 2020
A B S T R A C T

Farmers in flood prone areas mostly use only urea without any solid recommendations. Possibilities of recurrent flooding/submergence during the season are one of reasons for avoiding nutrient application, through it has a strong bearing on regeneration growth and yield of rice varieties after floods, hence suitable nutrient management strategies are essential to enhance the productivity. However, higher dose of $\mathrm{N}\left(60 \mathrm{Kg} \mathrm{ha}^{-1}\right.$ as basal) showed positive response on plant growth during submergence but higher elongation caused plant mortality during post oxidative phase. Meanwhile, popular package and practices among flood prone farmers, addition of Zero $\mathrm{Kg} \mathrm{N}$ before submergence to minimized risk was not justified. So far, higher $\mathrm{N}$ applied as basal showed negative effect on survival during post submergence. Plants grown without $\mathrm{N}$ fertilizer before submergence showed 12-23\% plant mortality in both Sub-1 rice varieties during post oxidative phase even though submerged field was substituted with higher dose of N @60 $\mathrm{kg} \mathrm{ha}{ }^{-1}$ at $5^{\text {th }}$ days after desubmergence, mainly due to energy starvation during submergence. After de-submergence frequent addition of split doses of $\mathrm{N}$ might be helpful to meet out the demand of submerged plants for faster recovery.

\section{Introduction}

Rice is semi aquatic plants. Thus, traditionally grown rice cultivars in flooded soil have a reputation for growing well under flooded conditions. About 22 million ha of rice in South Asia is prone to flash flooding. In India, about 17.4 million ha of rainfed lowland rice are grown each year, of which 5.2 million ha are submergence-prone, out of the 2.65 million ha flash-flood prone areas, about 1.6 million ha rice are frequently inundated. Even during normal years, approximately $20 \%$ of the geographical area is affected by flooding, due to serious crisis most of the rice cultivars die within days of complete submergence, often resulting in total crop loss (Mackill et al., 2012).

These losses heavily affect rice farmers where alternative livelihood and food security options are limited. Farmers of flood prone 
ecosystem kept their land fallow because of severe water stagnation. The productivity of such area is also very low because of excess water inundation and flooding. Overall, the estimated annual yield loss in deep water ecosystem alone amount to 1 million $t$. it these losses are particularly recovered, the average productivity in rainfed lowlands and flood prone area can be easily raised to $2 \mathrm{t}$ ha 1 . A wide knowledge gap still exists between researchers and farmers about the need and progress in rice technology development for flood-prone ecosystem. Even the available technologies are not adopted by farmers because of inherent risk of crop failure and runoff losses of nutrient during floods. Poor characteristics of the soil and hydrology of flood prone environments also seems to limit technology development and option on a wider scale.

One of the major constraints to rice productivity enhancement across flood prone environment is lack of suitable improved seed, nutrient efficient and responsive varieties. The recent progress in knowledge about the development of flood tolerant varieties like Swarna Sub-1 and other sub1 consisting mega rice varieties. Sub-1 gene introgressed in it showed higher yield and survival in comparison to original Swarna, IRRI showed that sub-1varieties give an average of 1-3.8 tones higher yield than nonsub-1types under 12-17 days of complete submergence (Singh et al., 2009) and which is still grown over 5 million ha and is currently the most popular rice variety of India.

Apart from this new technology developed for flood tolerant varieties, $S U B 1 A$ gene has been transferred to 8 rice varieties, including the five mega rice varieties of India and Bangladesh (Collard et al., 2013). The new versions have a small segment of the donor genome containing $S U B 1 A$, while retaining the entire genome of the original varieties
(Sarkar and Bhattacharjee, 2011). SUB1A was subsequently identified as the major determinant of submergence tolerance (Singh et al., 2010). In addition, balanced nutrition (NPK and FYM) together with lower seedling density in the seedbed are also very crucial in realizing full potential of these flood tolerant varieties. Recent research has shown that leaf $\mathrm{N}$ concentration is negatively correlated with plant survival under flooded conditions and addition of $\mathrm{P}$ seemed to enhance tolerance of plants grown on P-deficient soil (Ella and Ismail, 2006) or rainfed lowland soils (Singh et.al.,2006).

In Sub1 rice, during flooding leaf foliage's are decayed and after de-submergence new leaves emerged. Therefore, rice plants needs more $\mathrm{N}$ for faster recovery after desubmergence. Existing recommendation is not sufficient to fulfill the requirements of submerged rice plants. Most of the $\mathrm{N}$ flashes out due to flooding. Experiments on nutrient management before and after flooding ("recovery") reveal that significant increase in yield could be achieved through application of nutrients, particularly nitrogen, because of its effects on stimulating recovery and early tillering (Ram et al., 2009). The rudimentary objective of this investigation is not to replace the existing recommendations; but to provide knowledge and advice on how these recommendations need to be adjusted in flood-prone areas.

\section{Materials and Methods}

The field experiment was conducted in wet seasons of two consecutive year 2018 and 2019 at the Instructional Farm, Department of Crop Physiology, Narendra Dev University of Agriculture and Technology, Kumarganj, Faizabad, situated between a latitude of $26^{0} .47^{\prime}$ north and longitude of $82^{0} .12^{\prime}$ east, on altitude of 113 meters above sea level in the gangetic alluvium of eastern Uttar Pradesh, 
India. Present study, two $S u b$-1 rice varieties were used (Sambha Mahsuri Sub-1: V1, BR11 Sub-1 V2. Nursery raising, seeds of Sambha Mahsuri Sub-1 and BR-11 Sub1varieties were sown@100g/ $\mathrm{m}^{2}$ in $2 \times 2 \mathrm{~m}^{2}$ plot size. Transplanting was done in newly constructed cemented submergence tank (size: 20x17x1.5m; ground surface was not cemented). Thirty days old seedlings were transplanted at the spacing of 20x $15 \mathrm{~cm}$ using multiple seedlings per hill in plot size $2.5 \times 2 \mathrm{~m}^{2}$ in Randomized completely block design (RCBD) with 3 replications.

The experiments were comprises three nitrogen management practices including recommended practice ( $@ \mathrm{~N}_{120}: \mathrm{P}_{40}: \mathrm{K}_{40} \mathrm{Kg}$ ha $\left.{ }^{1}\right)$ i.e. $\left(\mathrm{T}_{1}\right) \frac{1}{2} \mathrm{~N}\left(60 \mathrm{Kg}^{-1}\right.$ through urea)and full dose of $\mathrm{P}$ (single super phosphate) and $\mathrm{K}$ (muriate of potash) applied at the time of transplanting and rest $\mathrm{N}$ apply in two split at consecutive $5^{\text {th }}$ day after de-submergence and 1 week before flowering; $\left(\mathrm{T}_{2}\right): 1 / 4 \mathrm{~N}(30 \mathrm{Kg}$ $\mathrm{ha}^{-1}$ ) and full dose of $\mathrm{P}$ and $\mathrm{K}$ of recommended dose was applied at the time of transplanting, rest $\mathrm{N}$ applied in three split(@ $30 \mathrm{Kg} \mathrm{ha}^{-1}$ in each), at $5^{\text {th }}$ day, at $20^{\text {th }}$ day desubmergence (at recovery) and 1 week before flowering and farmers practices of flood prone ecosystem(T3), only P and K (@40 Kg $\mathrm{ha}^{-1}$ ) were applied as basal at the time of transplanting (BS) and $\mathrm{N}$ was applied during post flood@60, 30 and $30 \mathrm{Kg} \mathrm{N} \mathrm{ha}^{-1}$ at $5^{\text {th }}$ days, $20^{\text {th }}$ days de submergence and one week before flowering respectively.

Stagnant submergence treatment was given at 60 days crop age (after 30 days transplanting) in submergence tanks. $40-45 \mathrm{~cm}$ water depth was maintained by fresh water till $18^{\text {th }}$ day of complete submergence.Plant survival was recorded at $5^{\text {th }}$ and $20^{\text {th }}$ days (at recovery) after desubmergence respectively. Recommended agronomic cultural practices and protective measure were applied accordingly. Three plants per replicate were initially tagged for growth observations which were recorded over three replications. Growth observations viz. plant height $(\mathrm{cm})$, tiller number plant $^{-1}$, survival (\%), dry weight $(\mathrm{mg} / \mathrm{p})$, soluble sugar content $(\mathrm{mg} /$ dry wt.), N-content (\%), N-uptake $\left(\mathrm{Kg} / \mathrm{ha}^{-1}\right), \mathrm{N}$ use efficiency, days of $50 \%$ flowering, days to physiological maturity, regenerations (new leaf emergence) were taken at three consecutive events i.e. before submergence, after de-submergence and at recovery stage. The total regenerated plants and new leaf emergence are counted at $5^{\text {th }}$ days de submergence and recovery stage (after 20 days de-submergence).

\section{Biochemical analysis}

Biochemical estimation and nutrient analysis was done at before submergence, just after submergence, at recovery and maturity stages. Traits and methodology used viz; Total chlorophyll content (Arnon 1949), total soluble sugar (Yemm and Willis 1954), nitrogen content (Linder 1944), nitrogen uptake (computed in $\mathrm{Kg} \mathrm{ha}^{-1}$ ), nitrogen use efficiency (Quanbao et al., 2007). The statistical analysis of treatment on the patterns of randomized completely block design (RCBD) was carried out. The data were analyzed by appropriate statistical analysis (Gomez and Gomez, 1984).

\section{Results and Discussion}

In the present investigation various parameters used for evaluation of split doses of $\mathrm{N}$, time of application and its combination with $\mathrm{P}$ and $\mathrm{K}$. In normal condition application of higher nitrogen fertilizer alone or with potassium and phosphorus provide motility or strength to the plant. Application of nitrogen in main field greatly increases vigor in terms of plant height and dry matter accumulation before submergence in Sambha Mahsuri Sub1 and BR-11 Sub-1 rice varieties. Growth 
parameters like plant height showed higher values (45-52) for the treatment with application of $60 \mathrm{Kg} \mathrm{ha}^{-1} \mathrm{~N}$ in combination with $\mathrm{P} 40 \mathrm{Kg} \mathrm{ha}^{-1}$ and $\mathrm{K} 40 \mathrm{Kg} \mathrm{ha}^{-1}$ as basal in both sub-1 rice varieties (Table 1). It seems that high nitrogen in combination with phosphorus and potassium helpful in shoot growth. Present study also indicated that chlorophyll content and nitrogen uptake in treatment comprises higher dose of nitrogen was considerably more than lower dose and Zero $\mathrm{Kg} \mathrm{ha}^{-1} \mathrm{~N}$ applied as basal. The uptake of higher nitrogen was observed in $\mathrm{T}_{1}$ followed by $\mathrm{T}_{2}$ and $\mathrm{T}_{3}$ i.e., $\left(0.87-0.59 \mathrm{Kgha}^{-1}\right)$, (0.67$\left.0.53 \mathrm{Kgha}^{-1}\right)$, (0.19-0.17 $\left.\mathrm{Kgha}^{-1}\right)$ in Sambha Mahsuri Subl and BR-11 Subl respectively. It is clearly indicated that higher dose of $\mathrm{N}$ helps in crop establishment, the above hypothesis also supported by Cassman and Stephen (2003). Significantly Subl rice varieties showed more than $90 \%$ survival and higher elongation rate when 60 days old plants were subjected for 18 days complete submergence in clear water and stagnant condition. Plant mortality due to submergence was very less in all treatments, because of older plant has paid advantages to sustained plant growth during submergence. Survival percentage was recorded after $5^{\text {th }}$ day of desubmergence maximum survival was recorded with $\left(\mathrm{N} 30 \mathrm{Kgha}^{-1}\right)$ followed by $\left(\mathrm{N} 60 \mathrm{Kgha}^{-1}\right.$ ) and (N0 $\mathrm{Kgha}^{-1}$ ) i.e., (100\%), (98-99\%), (93-94\%) respectively. Recent studies also indicated that older seedling up to (40-45days) had better survival than younger seedling (21-25days). Chaturvedi et.al (1995), reported that old seedling tend to have large carbohydrate reserves, therefore good survival during submergence. Present investigation, in spite of Subl-mediated suppression of elongation both Subl rice varieties showed (1.67 to $1.75 \mathrm{~mm} /$ day) elongation during submergence. This study clearly indicates indicated that shoot elongation during submergence act as constitutive traits when plant vigor enhanced through proper nutrient management before flood onset or older seedling subjected to flooding. Similarly in contrast Voesenek et al., 2006 reported that rapid shoot elongation increases carbohydrate consumption which resulting less survival percentage after flooding and Ella and Ismail 2006 also suggested that plant enrichment with nitrogen before submergence adversely affected survival after submergence. The correlation study clearly indicated that negative correlation between survival and $\mathrm{N}$ uptake $(r=-0.09)$. The adverse effect of submergence of observed in post submergence phase when plants experience sudden increases in $\mathrm{O}_{2}$ concentration on the re-entry of air after submergence. Visual symptoms of injury normally are not apparent immediately after submergence, but these symptoms develop gradually during the postoxidative phase. Present study also reflected that higher dose (N60:P40:K40 $\mathrm{Kgha}^{-1}$ ) or imbalanced fertilizer (N0:P40:K40 $\mathrm{Kgha}^{-1}$ ) resulted higher seedling mortality when flood receded from field. Several studies revealed that post oxidative damage leads tissue death. Setter et.al (2010) reported that after desubmergence leaf desiccated mainly due to large reduction in hydraulic conductivity in the leaf sheath. The water deficits are an important cause in the sequence of events rather than a mere result of injury. Survival after 20 days of de-submergence was higher when $\left(30 \mathrm{Kgha}^{-1}\right) \mathrm{N}$ were applied as basal followed by $\left(60 \mathrm{Kgha}^{-1}\right) \mathrm{N}$ were applied as basal before submergence. Subsequently advantages of $\mathrm{N}$ rich plants of Subl rice varieties were observed in respect to faster recovery. Initial plant grown with $\left(0 \mathrm{Kgha}^{-1}\right) \mathrm{N}$ before submergence exhausted soon therefore, higher plants mortality was recorded at $20^{\text {th }}$ day of de-submergence. Present study showed that maximum mortality were recorded (11.6 to 23.3) followed with higher doses of $\mathrm{N}$ (6.03 to 14.4) and (2.3 to 3.9) of both Subl rice varieties. Maximum mortality was obtained with $\left(0 \mathrm{~N} \mathrm{Kgha}^{-1}\right.$ as basal before 
submergence) because of plant suddenly shifted from anaerobic to aerobic condition so, that post oxidative damage done and reason for post oxidative damage is before submergence plant vigor was poor and plant were weaker in comparison to treatments $T_{1}$ and $\mathrm{T}_{2}\left(60 \mathrm{Kgha}^{-1}\right.$ and $30 \mathrm{Kgha}^{-1}$ as basal respectively). So, that very less soluble $\mathrm{CHO}$ was available to generate more energy for their survival as well as for growth and development under submerged condition. Unlikely in $T_{1}$ and $T_{2}$ shoot elongation is higher during submergence resulting in poor vigor's which causes tissue damage and mortality (Table.2). Further data generated regarding regeneration at recovery indicates that post submergence nitrogen application in field might be beneficial for recovery growth. Significantly the response of nitrogen was clearly shown in $\mathrm{T} 3\left(0 \mathrm{Kg} \mathrm{ha}^{-1} \mathrm{~N}\right)$ applied as basal. The correlation study clearly indicate that strong positive correlation between survival and $\mathrm{N}$ content $(\mathrm{r}=0.85)$. Growth parameters like the dry weight and $\mathrm{N}$ uptake showed significantly high values (307-300\%) and (550-300\%) respectively (Table.3).

Table.1 Effect of nitrogen management on survival (\%), regeneration and new leaf emergence of Sub1 rice varieties grown under submerged condition (18 days of complete submergence)

\begin{tabular}{|c|c|c|c|c|c|c|}
\hline \multirow{2}{*}{$\begin{array}{c}\text { Treatments } \\
\text { T1V1 }\end{array}$} & \multirow{2}{*}{$\begin{array}{c}\text { Plant no. before } \\
\text { submergence/ plot }\end{array}$} & \multirow{2}{*}{$\begin{array}{c}\begin{array}{c}\text { Plant no. after } \\
\text { submergence/ plot }\end{array} \\
255 \\
\end{array}$} & \multicolumn{2}{|c|}{$\begin{array}{l}\text { Survival at } 5^{\text {th }} \& \\
20^{\text {th }} \text { day after de- } \\
\text { submergence }(\%)\end{array}$} & \multirow{2}{*}{ 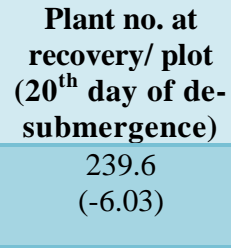 } & \multirow{2}{*}{$\begin{array}{c}\text { New leaf emergence } \\
\begin{array}{c}5^{\text {th }} \text { day } \\
\text { desubmergence }\end{array}\end{array}$} \\
\hline & & & 99 & 93.9 & & \\
\hline T2V1 & 256 & 255 & 100 & 97.6 & $\begin{array}{l}249.0 \\
(-2.3)\end{array}$ & -do- \\
\hline T3V1 & 261 & 250 & 97 & 88.4 & $\begin{array}{l}221.0 \\
(-11.6)\end{array}$ & -do- \\
\hline T1V2 & 264 & 261 & 98 & 92 & $\begin{array}{c}240.3 \\
(-14.4)\end{array}$ & -do- \\
\hline T2V2 & 280 & 280 & 100 & 96 & $\begin{array}{l}269.0 \\
(-3.9)\end{array}$ & -do- \\
\hline T3V2 & 294 & 287 & 93 & 76.6 & $\begin{array}{c}220.0 \\
(-23.3)\end{array}$ & -do- \\
\hline Interaction & $\mathrm{V} \times \mathrm{T}$ & V & & & & \\
\hline CD at $5 \%$ & 6.37 & 3.68 & & & & \\
\hline
\end{tabular}

Table.2 Effect of nitrogen management on plant height $(\mathrm{cm})$ and dry weight $(\mathrm{g})$ of Sub1 rice varieties grown under submerged condition (18 days of complete submergence

\begin{tabular}{|c|c|c|c|c|c|c|c|}
\hline \multirow[t]{2}{*}{ Treatments } & \multicolumn{2}{|c|}{ Before submergence } & \multicolumn{2}{|c|}{ After submergence } & \multirow[t]{2}{*}{$\begin{array}{c}\text { Elongation } \\
\text { (mm/day) }\end{array}$} & \multicolumn{2}{|c|}{$\begin{array}{l}\text { At recovery }\left(20^{\text {th }} \text { day }\right. \\
\text { after de-submergence) }\end{array}$} \\
\hline & Plant height & $\begin{array}{l}\text { Dry } \\
\text { weight }\end{array}$ & $\begin{array}{l}\text { Plant } \\
\text { height }\end{array}$ & $\begin{array}{c}\text { Dry } \\
\text { weight }\end{array}$ & & $\begin{array}{l}\text { Plant } \\
\text { height }\end{array}$ & $\begin{array}{c}\text { Dry } \\
\text { weight }\end{array}$ \\
\hline $\mathbf{T 1}$ & 48.9 & 3.23 & 79.6 & 2.28 & 1.70 & 101.4 & 3.83 \\
\hline $\mathbf{T} 2$ & 44.4 & 3.11 & 72.3 & 2.02 & 1.55 & 105.8 & 4.11 \\
\hline T3 & 39.6 & 2.72 & 57.2 & 1.16 & 0.97 & 77.2 & 4.68 \\
\hline $\mathrm{CD}(\mathrm{P}=0.05)$ & 3.11 & 0.23 & 5.78 & 0.09 & NS & 3.45 & 0.15 \\
\hline
\end{tabular}


Table.3 Effect of nitrogen management on total chlorophyll content ( $\mathrm{mg} \mathrm{g}^{-1}$ fresh weight), carbohydrate content (mg/g dry wt. of leaf) and nitrogen content (\%) in shoot of Sub1 rice varieties grown under submerged condition (18 days of complete submergence)

\begin{tabular}{|c|c|c|c|c|c|c|c|c|c|}
\hline \multirow[t]{2}{*}{ Treatments } & \multicolumn{3}{|c|}{ Before submergence } & \multicolumn{3}{|c|}{ After submergence } & \multicolumn{3}{|c|}{$\begin{array}{l}\text { At recovery }\left(20^{\text {th }} \text { day }\right. \\
\text { after de-submergence })\end{array}$} \\
\hline & $\begin{array}{c}\text { Total } \\
\text { Chlorophyll } \\
\text { content }\end{array}$ & $\begin{array}{c}\text { Soluble } \\
\text { Sugar } \\
\text { content }\end{array}$ & $\mathrm{N}$ content & $\begin{array}{c}\text { Total } \\
\text { Chlorophyll } \\
\text { content }\end{array}$ & $\begin{array}{c}\text { Soluble } \\
\text { Sugar } \\
\text { content }\end{array}$ & $\mathrm{N}$ content & $\begin{array}{c}\text { Total } \\
\text { Chlorophyl } \\
1 \text { content }\end{array}$ & $\begin{array}{c}\text { Soluble } \\
\text { Sugar } \\
\text { content }\end{array}$ & $\mathrm{N}$ content \\
\hline T1 & 1.60 & 160 & 1.67 & 0.84 & 121 & 0.90 & 2.06 & 130 & 1.10 \\
\hline $\mathbf{T} 2$ & 1.38 & 142 & 1.61 & 0.64 & 112 & 0.80 & 2.62 & 128 & 1.21 \\
\hline T3 & 0.87 & 103 & 0.90 & 0.38 & 78 & 0.53 & 3.06 & 142 & 1.40 \\
\hline $\mathrm{CD}(\mathbf{P}=\mathbf{0 . 0 5})$ & 0.90 & 6.63 & 0.19 & 0.32 & 3.77 & 3.25 & 3.08 & 4.94 & 0.39 \\
\hline
\end{tabular}

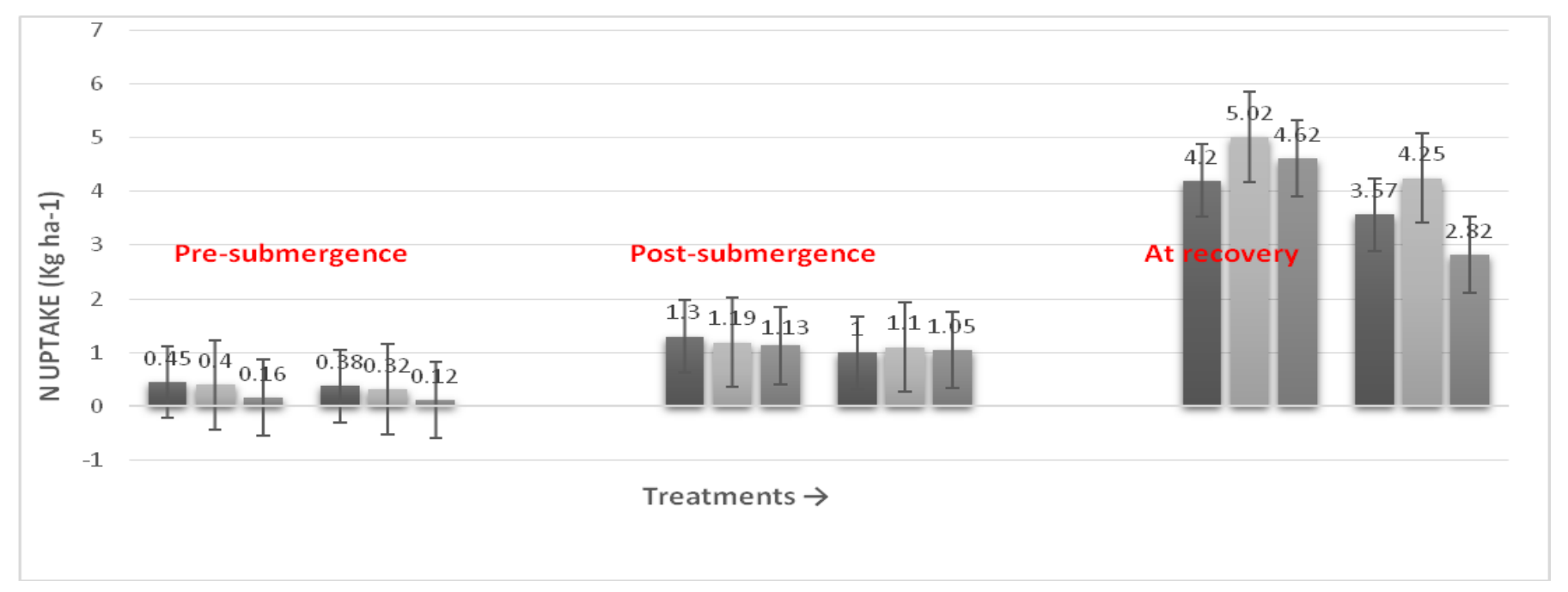

Fig.1 Effect of nitrogen management on $\mathrm{N}$ uptake $\left(\mathrm{Kgha}^{-1}\right)$ of Sub1 rice varieties grown under submerged condition (18 days of complete submergence

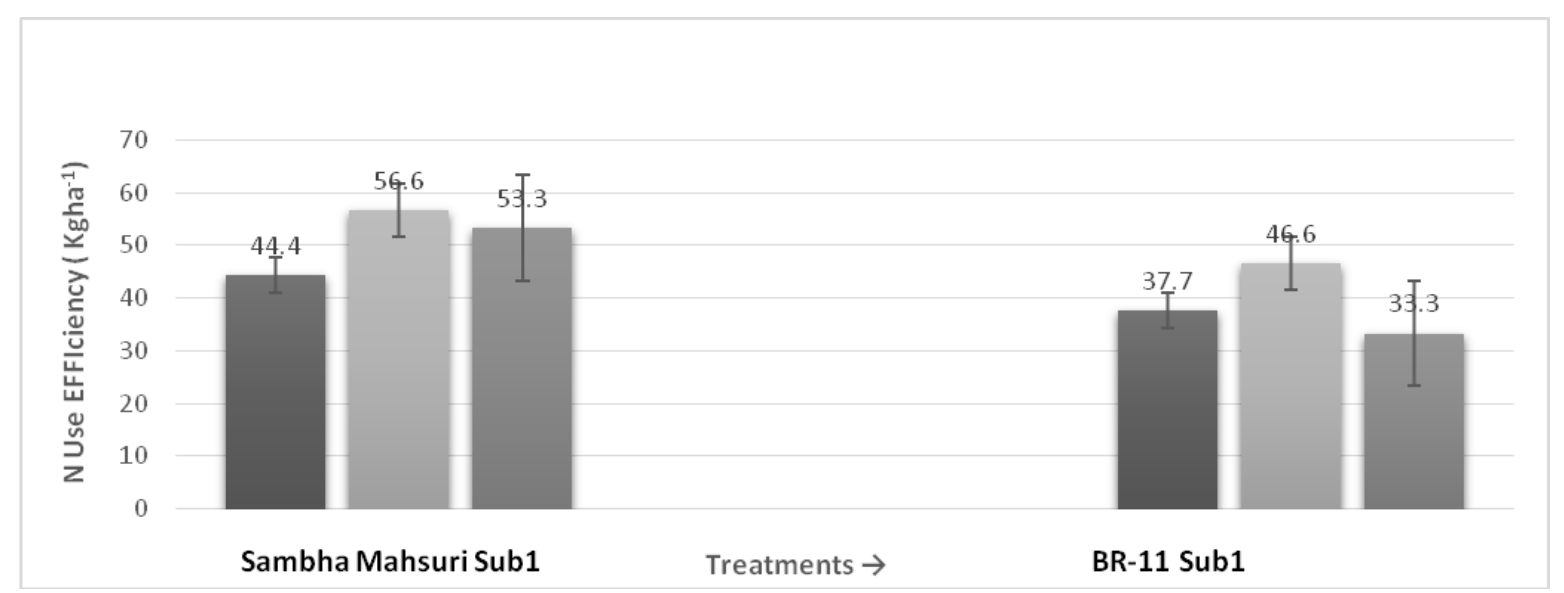

Fig.2 Effect of nitrogen management on $\mathrm{N}$ use efficiency $\left(\mathrm{Kgha}^{-1}\right)$ of Sub1 rice varieties grown under submerged condition (18 days of complete submergence) 
It is concluded that nitrogen management in main field for subl interrogated rice varieties is not clear yet. Recommended package $\left(\mathrm{N}_{120}: \mathrm{K}_{40}: \mathrm{K}_{40} \mathrm{Kgha}^{-1}\right)$ and practices $60 \mathrm{Kgha}^{-1}$ (1/2 dose of $\mathrm{N}$ ) applied as basal was found not beneficial for subl interrogated rice varieties. It induced higher elongation when plants were subject for 18 days complete submergence compared with $30 \mathrm{Kgha}^{-1} \mathrm{~N}$ and zeroKgha ${ }^{-1} \mathrm{~N}$ with $40 \mathrm{Kgha}^{-1} \mathrm{P}$ and $\mathrm{K}$ applied as basal.

Present investigation recommended dose of $\mathrm{N}$ was adjusted with four split doses i.e. $30 \mathrm{Kgha}^{-1}$ with combination of $40 \mathrm{Kgha}^{-1} \mathrm{P}$ and $\mathrm{K}$ applied as basal, subsequently rest $\mathrm{N}$ was applied $5^{\text {th }}, 20^{\text {th }}$ days de-submergence and one week before flowering. Further, application of $\mathrm{N}$ was tested according to adopted practices of farmers, avoid to loss due to heavy rainfall i.e. $60 \mathrm{Kgha}^{-1} \mathrm{~N}$ applied as basal $5^{\text {th }}$ day of desubmergence and consequently rest amount of $\mathrm{N}$ applied in two split doses $\left(30 \mathrm{Kgha}^{-1}\right.$ each) at $20^{\text {th }}$ days de-submergence and one week before flowering.

Maximum survival was obtained i.e. 97.6 and 92.0 percent in Sambha Mahsuri subl and BR-11 sub1 respectively. Therefore, higher dose of $\mathrm{N}$ as basal induce shoot elongation during submergence. Several other studies indicated that higher dose of $\mathrm{N}$ is found nonsignificant; Ella and Ismail (2006) reported that higher ' $N$ ' concentration of rice leaves is not beneficial when rice is subjected to flash flooding. In case of $0 \mathrm{Kgha}^{-1} \mathrm{~N}$ and rest $\mathrm{N}$ applied in three split doses i.e. $\left(5^{\text {th }}, 20^{\text {th }}\right.$, and $60^{\text {th }}$ days after transplanting) was found nonbeneficial due to poor vigor of plant before submergence.

Thus found more mortality $\%$ at recovery ( $20^{\text {th }} \mathrm{d}$ after de-submergence) stage of plant. Higher dose of $\mathrm{N}\left(60 \mathrm{Kg} \mathrm{ha}^{-1}\right)$ and Zero $\mathrm{Kg} \mathrm{N}$ $\mathrm{ha}^{-1}$ were found non-beneficial due low survival $\%$ at post-oxidative phase. Whereas, in case of $\left(30 \mathrm{Kgha}^{-1}\right) \mathrm{N}$ as basal and rest $\mathrm{N}$ is applied in three split doses i.e. $\left(5^{\text {th }}\right.$ and $20^{\text {th }}$ day after de-submergence and one week before flowering found beneficial and effective in submergence condition due to mortality $\%$ counted very squat after 18 days of complete submergence and at postoxidative phase.

However, application of lower dose of N (30 $\mathrm{Kgha}^{-1}$ ) as basal and rest amount of $\mathrm{N}$ in three split doses along with $\mathrm{P}$ and $\mathrm{K}\left(40 \mathrm{Kgha}^{-1}\right)$ in field might be exploit to improve submergence tolerance and to obtained higher yield under flood prone eco-system due to higher survival after de- submergence corresponding to less post-oxidative damage through proper $\mathrm{N}$ management during, before and post submergence period.

\section{References}

Cassman, K.G. and Stephen, C. (2008). Importance and Effect of Nitrogen on Crop Quality and Health. Book chapter Published in Nitrogen in the Environment: Sources, Problems, and Management, Second edition, edited by J. L. Hatfield and R. F. Follett (Amsterdam: Elsevier, 2008).

Chaturvedi, G.S.; Ram, P.C.; Singh, A.K.; Ram, P.; Ingram, K.T.; Singh, B.B.; Singh, R.K.; Singh, V.P.; (1996). Carbohydrate status of rainfed lowland rice's in relation to submergence, drought and shade tolerance. In: Singh V P et al., (Eds.), Physiology of stress tolerance in rice, proceedings of the International Conference on Stress Physiology of Rice, February 28 and March 5, 1994, Lucknow, UP, India, pp.103-122.

Collard, BCY; Septiningsih, E.M.; Das, S.R.; Carandang, J.J.; Pamplona, A.M.; Sanchez, D.L.; Kato, Y; Ye,G; Reddy, J.N.; Singh, U.S.; Iftekharuddaula, K.M.; Venuprasad, R.; Vera-Cruz, 
C.N.; Mackill, D.J.; Ismail, A.M. (2013). Developing new flood-tolerant varieties at the International Rice Research Institute (IRRI). SABRAO J. Breed. Genet. 45: 42-56.

Ella, E.S.; Ismail, A.M.; (2006). Seedling nutrient status before submergence affects survival after submergence in rice. Crop Sci. 46, 1673-168.

Mackill, D.J.; Ismail, A.M.; Singh, U.S.; Labios, R.V.; Paris, T.R. (2012). Development and rapid adoption of submergence-tolerant (Sub1) rice varieties. Adv. Agron. 115: 303-356.

Ram,P.C.; Mazid, M.A; Singh, P.N; Singh, V.N; Haque, M.A; Singh, U; Ella, E.S. and Singh, B. B.(2009).Crop resource management in flood prone areas:farmer's strategies and research developments. Proceeding of the NRM workshop, Bangladesh (in press).

Sarkar, R.K., De, R.N., Reddy, J. N. and Ramakrishnaya, G. (1996). Studies on the submergence tolerance mechanism in relation to carbohydrate, chlorophyll and specific leaf weight in rice (Oryza sativa L.). J. Plant Physiol., 149: 623625.

Septiningsh, E.M., Pampiona, A.M.,Sanchez, DL;Maghirang- Rodriguez R; Neeraja, C.N.;Vergara, G.V.,Heuer., Ismail, A.M. and Mackill, D.J. (2009).Development of submergencetolerant rice cultivars: the Sub1 gene and beyond.Ann.Bot.103:151-160.

Setter, T.L., Bhekasut, P., Greenway, H.,
(2010). Desiccation of leaves after desubmergence is one cause for intolerance to complete submergence of the rice cultivar IR 42. Funct. Plant Biol. 37, 1096-1104.

Singh, N.; Dang, T.T.M.; Vergara, G.V.; Pandey, D.V.;Sanchez, D.; Neeraja, C.N.; Septiningsih, E.M.; Mendioro, M.; Tecson-Mendoza, E.M.; Ismail, A.M.; Mackill, D.J.; Heuer, S.(2010). Molecular marker survey and expression analysis of the rice submergence tolerance gene SUB $1 A$. Theor. Appl. Genet. 121: 1441-1453.

Sarkar, R.K.;Bhattacharjee, B. (2011). Rice genotypes with SUB1 QTL differ in submergence tolerance, elongation ability during submergence and regeneration growth at re-emergence. Rice 2011, 5:7.

Voesenek, LACJ. Colmer, T.D., Pierik, R., Millenaar, FF., Peeters, AJM. (2006). Tansley review. How plants cope with complete submergence. New Phytologist 170: 213-226.

Xu, K.; Xia, X.; Fukao, T.; Canlas, P.; Maghirang, R.R.; Heuer, S.; Ismail, A.M.; Mackill, D.J.; Bailey-Serres, J.;Ronald, P.C.(2006). Sub1A is an ethylene response factor-like gene that confers submergence tolerance to rice. Nature. 442: 705-708.

Yemm, E.W. and Willis, A. J. (1954). This estimation of carbohydrate in plant extracts by anthrone. Biochem. J. 57: 508-514.

\section{How to cite this article:}

Anand Kumar Pandey, A. K. Singh, Alok Kumar Singh and Yadav. R. K. 2020. A Physiological Approach: Nitrogen Management and Sub-1 Rice Varieties Grown in Flood Prone Ecosystem. Int.J.Curr.Microbiol.App.Sci. 9(05): 38-45. doi: https://doi.org/10.20546/ijcmas.2020.905.003 